\title{
EFFECT OF CARBARYL ON SOME BIOCHEMICAL CONSTITUENTS OF THE BLOOD AND LIVER OF CLARIAS BATRACHUS, A FRESH-WATER TELEOST
}

\author{
Bechan SHARMA \\ Biochemical Toxicology Laboratory, Department of Biochemistry, \\ Dr. R. M. L. Avadh University, Faizabad-224001, India
}

(Received January 8, 1999 ; Accepted May 14, 1999)

\begin{abstract}
Carbaryl, a carbamate pesticide, (LC50 $15.08 \mathrm{mg} / \mathrm{l}$ for $96 \mathrm{hr}$, i. e. lethal concentration with $50 \%$ mortality) induced perturbations in the levels of certain biochemical components including the activities of some enzymes in the blood and liver of the fresh-water catfish, Clarias batrachus exposed to sublethal concentrations $(1,2$ and $4 \mathrm{mg} / \mathrm{l})$ of the pesticide for $96 \mathrm{hr}$ and 15 days. The pesticide caused a decrease in the levels of total protein and glucose with a concomitant increase in the levels of inorganic phosphate and lactic acid in fish serum. However, very little change was recorded in the serum cholesterol level. The treatment of the fish with carbaryl led to a marked increase in the activities of transaminases (GOT and GPT), phosphatases (acid and alkaline) and lactate dehydrogenase in the fish serum, the magnitude of the effect being dependent on the pesticide concentration and duration of exposure. The increase in lactic acid concentration with subsequent decrease in glucose concentration indicates an enhanced rate of glycolysis due to pesticide stress. Furthermore, the significant decrease in the activity of fish liver succinate dehydrogenase suggests that anaerobic metabolism was favored over aerobic oxidation of glucose through Kreb's cycle in order to mitigate the energy crisis for survival. The rise in the activities of transaminases and acid phosphatase due to pesticide intoxication suggest enhanced protein catabolism and probable hepatocellular damage in the organism.
\end{abstract}

KEY WORDS: Clarias batrachus, Carbaryl, Carbamate pesticide, Protein metabolism, Enzymes

\section{INTRODUCTION}

Paddy fields and low land areas in Northeastern India are natural habitats of the air-breathing catfish, Clarias batrachus (Linn.). It is an edible fish found in ponds, lakes and rivers in India. It possesses four pairs of barbles which are sensitive to $\mathrm{pH}$, salinity and temperature of the medium. The presence of paired barbles around the mouth makes its appearance like that of a cat. It is therefore called a catfish. With the accepted use of pesticides in agriculture, their effects on the overall growth, metabolism and reproduction of fish cannot be ruled out. Although the toxic actions of pesticides such as organocarbamates on the target pests and also on some terrestrial populations have been evaluated and studied extensively, their effects on non-target animals such as fish await detailed investigations. The choice of the fish species for study is only due to its production potential from paddy fields and stagnant shallow ponds (Mukhopadhyay et al., 1982).

The hazards of pesticides to fish are of great concern. In recent years, incidences of fish mortality due to industrial effluents, sewage pollution and pesticides have been reported (Mowdesley Thomas, 1971). Pesticides have been found to be highly toxic not only to fishes but also to fish-food organisms. A number of reports have appeared in recent years on the uptake and tissue distribution of pesticides in various fishes (Kaundilya and Ramamurti, 1980). Therefore, it is important to examine the toxic effects of pesticides on fish as they form an important part of human food.

Carbaryl ( $\alpha$-naphthyl 1-methyl carbamate), a car- 
bamate pesticide, has a wide range of applications in agriculture as an effective systemic pesticide. The carbaryl-induced inhibition of enzyme activity and its additional biochemical effects have not been studied in much detail, particularly in commercially important food fish. However, Sastry and Siddiqui (1982) have reported that the carbamate, sevin, induced hyperlactemia as well as changes in the activities of some key enzymes of carbohydrate metabolism in different body tissues and blood of Channa punctatus, a snakehead fish.

The air-breathing catfish used in the present study, C. batrachus, is considered as one of the most suitable species for breeding and rearing in paddy fields because of its physiological and behavioral adaptations.

Earlier reports from this laboratory have shown that subacute concentrations of carbaryl induced drastic alterations in the level of biogenic amines in different parts of the brain of C. batrachus (Sharma et al., 1993b) and adversely affected fish behavior. Also, this pesticide at sublethal concentrations has been shown to cause perturbations in the activities of acetylcholinesterase (Sharma et al., 1993a) as well as lactate dehydrogenase (Sharma and Gopal, 1995) in the key organs of $C$. batrachus exposed to the pesticide. However, scanty reports are available concerning the effect of organocarbamate pesticides on the biochemical composition of fish serum. The present communication deals with the effect of carbaryl on some biochemical components of serum and liver of $C$. batrachus exposed to subacute concentrations of carbaryl for two different incubation periods, i. e. $96 \mathrm{hr}$ and 15 days.

\section{MATERIALS AND METHODS}

Carbaryl (technical grade, 99\% purity) in a crystalline form was obtained as a gift from Rallis India Ltd.-India. Potassium permanganate, acetone and all other reagents of high purity used for assays of some biomolecules including activities of certain key enzymes were procured from Sisco Research Laboratories Pvt. Ltd., India.

The healthy and alive fresh water teleost, $C$. batrachus (length 15-20 cm, weight 20-30 g) was obtained from a local fish market and brought to the laboratory in 20 liter plastic containers. The healthy fish were selected and treated with potassium permanganate solution $(0.5 \%, \mathrm{w} / \mathrm{v})$ for $5 \mathrm{~min}$ to remove any dermal adherent. The fish (90 Nos.) were acclimated for seven days in a rectangular aquarium $(50 \mathrm{l})$ containing tap water at room temperature $\left(26 \pm 2^{\circ} \mathrm{C}\right)$ with food ad libitum under standard laboratory conditions. The $\mathrm{LC}_{50}$ value of carbaryl (technical grade, purity $99 \%$ and dissolved in acetone) for $C$. batrachus has already been determined in our laboratory $(15.08 \mathrm{mg} / \mathrm{l}$ for $96 \mathrm{hr})$ (Sharma et al., 1993b). The fish were equally divided into six groups; three of them were exposed to sublethal concentrations of carbaryl $(1.0,2.0$ and $4.0 \mathrm{mg} / \mathrm{l})$ for two different exposure periods of $96 \mathrm{hr}$ and 15 days in glass jars, each of 101 capacity. The remaining three groups of the fish were used as controls and each of them was kept in a pesticide-free medium. Equal concentration of acetone was maintained in the control as carbaryl added to the experimental aquaria was dissolved in acetone. Acetone was used as a solvent for carbaryl since it is known to be non-toxic up to relatively high concentration (Sharma and Gopal, 1995). The fish were fed with boiled egg white and small pieces of goat liver in adequate amount. No mortality of the fish occurred during the experimental period. The aquaria were aerated daily for $6 \mathrm{hr}$ with compressed air using stone diffusers and the test medium of each experimental group was renewed once every 24 hr. Other conditions were the same as mentioned elsewhere (Sharma et al., 1993b).

At the end of the experimental period, the fishes were sacrificed and dissected. The liver was excised and collected from controls as well as the experimental fish. The tissue was thoroughly washed in normal saline and stored at $4{ }^{\circ} \mathrm{C}$ to be used within $2 \mathrm{hr}$. The blood samples (about $1 \mathrm{ml}$ ) collected by fish caudal vein puncture from each group were kept at $10{ }^{\circ} \mathrm{C}$ for $15 \mathrm{~min}$, centrifuged at $800 \times \mathrm{g}$ for $10 \mathrm{~min}$ in a refrigerated centrifuge, and the serum collected was used for estimation of the activities of certain key enzymes and the levels of some biomolecules.

The homogenate $(10 \%, w / v)$ of liver $(1 \mathrm{~g})$ was prepared in cold sucrose solution $(0.25 \mathrm{M})$ using PotterElvehjam homogenizer, the homogenate was centrifuged at $10,000 \times \mathrm{g}$ for $15 \mathrm{~min}$ in a refrigerated centrifuge, and the supernatant was collected for assay of the activities of certain enzymes. Protein in the serum as well as in the tissue extracts was determined according to Lowry et al. (1951). The estimations of inorganic phosphate (Oser, 1979), glucose (Park and Johnson, 1963), cholesterol (Zlatkis et al., 1953) and lactic acid (Barker and Summerson, 1941) were done in serum using standard procedures. The activities of lactate dehydrogenase (EC 1.1.1.28, LDH) (Kaushal and Sharma, 1985), acid phosphatase (EC 3.1.3.2) (Plummer, 1971), alkaline phosphatase (EC 3.1.3.1) (Plummer, 1971), glutamate oxaloacetate transaminase 
Carbaryl induced biochemical changes in Clarias batrachus.

(EC 2.6.1.1, GOT) (Bergemeyer, 1965) and glutamate pyruvate transaminase (EC 2.6.1.2, GPT) (Bergemeyer, 1965) were determined in the serum and liver extract. The activity of succinate dehydrogenase (EC 1.3.99.1, $\mathrm{SDH}$ ) was assayed in the liver extract (Srikantan and Krishnamurti, 1955).

\section{Statistical analysis}

All quantitative data were expressed as mean \pm $\mathrm{SD}$, and evaluated statistically. The differences between chemical-treated and control groups were analysed using Student's $t$-test (Fisher, 1950). The significant level was set at $\mathrm{p}<0.05$.

\section{RESULTS}

The carbaryl-treated fish exhibited apparent changes in body color (from pinkish gray to dark gray), opercular movement, surfacing and swimming activities when compared to that of controls. Carbaryl caused significant alterations in the levels of some biochemical indices (total protein, inorganic phosphate, glucose, cholesterol and lactic acid) as well as in the activities of some key enzymes (LDH, acid and alkaline phosphatases, GOT and GPT) in the serum of $C$. batrachus exposed to three sublethal concentrations of carbaryl (1,2 and $4 \mathrm{mg} / \mathrm{l})$ for two different periods i. e. $96 \mathrm{hr}$ and 15 days.

The average concentrations of total protein, inorganic phosphate, glucose, cholesterol and lactic acid in the serum of the control fish were found to be $3870 \pm$ $180,45.75 \pm 4.47,65.31 \pm 7.31,427.51 \pm 29.81$ and $432 \pm 31.07 \mathrm{mg} / 100 \mathrm{ml}$ respectively (Table 1 ).

The levels of total protein and glucose decreased in the blood of $C$. batrachus treated with subacute concentrations of carbaryl for two different exposure periods (Tables 1 and 2). The decrease in the levels of these biochemical constituents was more prominent (about 30 and $24 \%$ respectively) when the fish were exposed to a higher concentration $(4 \mathrm{mg} / \mathrm{l})$ of the pesticide for a prolonged period of exposure (15 days). The levels of inorganic phosphate, cholesterol and lactic acid registered an increase in serum of the fish exposed to varying subacute concentrations of the pesticide at both exposure periods. The alteration in the level of lactic acid in the fish serum was more marked than that of other parameters (Tables 1 and 2) after both treatment durations ( $96 \mathrm{hr}$ and 15 days), the values being higher at $96 \mathrm{hr}$ compared to that of 15 days. The pesticide at 1 $\mathrm{mg} / \mathrm{l}$ concentration was less effective than at its higher concentrations ( 2 and $4 \mathrm{mg} / \mathrm{l}$ ). The level of serum lactic acid concentration, however, did not increase significantly after $2 \mathrm{mg} / \mathrm{l}$ for $96 \mathrm{hr}$ (from $40 \%$ to $42 \%$ ) or 15 days (from $35 \%$ to $36 \%$ ) (Tables 1 and 2). The elevation in blood lactic acid level may be attributed to the damage of fish organs due to pesticide toxicity. However, very little change (up to $5 \%$ ) was recorded in the level of cholesterol in the serum of carbaryl-treated C. batrachus over controls.

The average values of the activities of some key

Table 1. Effect of carbaryl on the levels of certain biomolecules in the blood serum of $C$. batrachus exposed for $96 \mathrm{hr}$.

\begin{tabular}{|c|c|c|c|c|}
\hline \multirow[t]{2}{*}{ Parameters } & \multirow[t]{2}{*}{ Control } & \multicolumn{3}{|c|}{ Carbaryl (mg/l) } \\
\hline & & 1 & 2 & 4 \\
\hline $\begin{array}{l}\text { Total protein } \\
(\mathrm{g} / 100 \mathrm{ml})\end{array}$ & $3.87 \pm 0.18$ & $\begin{array}{l}3.72 \pm 0.16 \\
(-3.87)\end{array}$ & $\begin{array}{c}3.41 \pm 0.18 \\
(-11.89)\end{array}$ & $\begin{array}{l}3.00 \pm 0.17 \\
(-22.48)\end{array}$ \\
\hline $\begin{array}{l}\text { Inorganic-Phosphate } \\
(\mathrm{mg} / 100 \mathrm{ml})\end{array}$ & $45.75 \pm 0.47$ & $\begin{array}{c}46.23 \pm 0.48 \\
(+1.05)\end{array}$ & $\begin{array}{c}48.32 \pm 0.51 \\
(+5.62)\end{array}$ & $\begin{array}{c}53.11 \pm 0.12 \\
(+16.01)\end{array}$ \\
\hline $\begin{array}{l}\text { Glucose } \\
(\mathrm{mg} / 100 \mathrm{ml})\end{array}$ & $65.31 \pm 3.01$ & $\begin{array}{c}63.53 \pm 3.02 \\
(-2.73)\end{array}$ & $\begin{array}{c}60.37 \pm 3.04 \\
(-7.73)\end{array}$ & $\begin{array}{l}58.13 \pm 3.02 \\
(-10.99)\end{array}$ \\
\hline $\begin{array}{l}\text { Cholesterol } \\
(\mathrm{g} / 100 \mathrm{ml})\end{array}$ & $0.42 \pm 0.02$ & $\begin{array}{l}0.43 \pm 0.03 \\
(+2.38)\end{array}$ & $\begin{array}{l}0.44 \pm 0.03 \\
(+4.76)\end{array}$ & $\begin{array}{l}0.44 \pm 0.02 \\
(+4.76)\end{array}$ \\
\hline $\begin{array}{l}\text { Lactic acid } \\
(\mathrm{g} / 100 \mathrm{ml})\end{array}$ & $0.43 \pm 0.31$ & $\begin{array}{l}0.48 \pm 0.28 \\
(+11.63)\end{array}$ & $\begin{array}{c}0.60 \pm 0.31 \\
(+39.53)\end{array}$ & $\begin{array}{l}0.61 \pm 0.33 \\
(+41.86)\end{array}$ \\
\hline
\end{tabular}

Each value represents the mean \pm S.E.M. of five different observations. Values in parentheses are percent change over control.

Sample size $(n)=15$ 
enzymes such as LDH, acid phosphatase, alkaline phosphatase, GOT and GPT in the serum of the control fish were recorded to be $1.13 \pm 0.11,1.51 \pm 0.31,0.32 \pm$ $0.03,0.28 \pm 0.01$ and $0.03 \pm 0.001 \mathrm{IU} / \mathrm{mg}$ protein, respectively (Table 3). The exposure of $C$. batrachus to carbaryl resulted in drastic alterations in the activities of these enzymes in the fish serum. The results presented in Tables 3 and 4 demonstrate that carbaryl at sublethal concentrations evoked a significant increase in the levels of the enzymes in fish serum at both treatment durations. The increase in the activities of these enzymes was more pronounced when the fish was exposed to carbaryl at all subacute concentrations $(1,2$ and $4 \mathrm{mg} / \mathrm{l}$ ) for a longer period of exposure (15 days) than that for a shorter treatment duration $(96 \mathrm{hr})$. However, the increase in the activities of transaminases (GOT and GPT) was higher than that of phosphatases (acid and alkaline) and LDH in the serum of pesticidetreated fish (Tables 3 and 4).

When the activities of these enzymes were assayed in the extract of the liver of the fish exposed to subacute concentrations of the pesticide for 15 days, it was found that carbaryl induced perturbations in the activities of LDH, acid phosphatase and GOT, whereas small but significant changes were recorded in the activities of alkaline phosphatase and GPT (Table 5). The activities of LDH, SDH and phosphatases (both acid and alkaline) were found to be decreased by $35,24,19$ and $7 \%$, respectively, with a concomitant increase in the activ- ities of GPT (7\%) and GOT (122\%) when the fish was exposed to carbaryl $(4 \mathrm{mg} / \mathrm{l})$ for 15 days. The increase in the activity of GOT in fish liver was, however, much higher than that of GPT due to carbaryl intoxication. The results suggested that the fish liver functions were severely affected by the pesticide.

\section{DISCUSSION}

Pesticides at subacute concentrations have been shown to affect energy metabolism (Sastry and Siddiqui, 1982; Sharma and Gopal, 1995; Singh and Sharma, 1998), neurotransmission (Sharma et al., 1993a, 1993b), synthesis of lipids and proteins (Saxena et al., 1988), immune systems (Gopal et al., 1992) and the activities of certain key enzymes of some fresh-water fishes (Sastry and Siddiqui, 1982; Sharma et al., 1993a; Sharma and Gopal, 1995). The results of the present study demonstrated the increased levels of inorganic phosphate, cholesterol and lactic acid and decreased levels of total proteins and glucose in the serum of $C$. batrachus exposed to carbaryl at three sublethal concentrations (1,2 and $4 \mathrm{mg} / \mathrm{l})$ for two incubation periods ( $96 \mathrm{hr}$ and 15 days); indicating thereby the toxic effects of the pesticide on the fish. Similar results have been reported in Channa punctatus exposed to sublethal concentrations of quinolphos (Sastry and Siddiqui, 1984) and monocrotophos (Samuel and Sastry, 1989) as well as in C. batrachus exposed to organophosphorus insec-

Table 2. Effect of carbaryl on the levels of certain biomolecules in the blood serum of C. batrachus exposed for 15 days.

\begin{tabular}{|c|c|c|c|c|}
\hline \multirow[t]{2}{*}{ Parameters } & \multirow[t]{2}{*}{ Control } & \multicolumn{3}{|c|}{ Carbaryl (mg/l) } \\
\hline & & 1 & 2 & 4 \\
\hline $\begin{array}{l}\text { Total protein } \\
(\mathrm{g} / 100 \mathrm{ml})\end{array}$ & $3.87 \pm 0.18$ & $\begin{array}{c}3.59 \pm 0.20 \\
(-7.25)\end{array}$ & $\begin{array}{c}3.18 \pm 0.25 \\
(-17.83)\end{array}$ & $\begin{array}{l}2.70 \pm 0.33 \\
(-30.23)\end{array}$ \\
\hline $\begin{array}{l}\text { Inorganic-Phosphate } \\
(\mathrm{mg} / 100 \mathrm{ml})\end{array}$ & $45.75 \pm 2.70$ & $\begin{array}{c}47.25 \pm 2.31 \\
(+3.28)\end{array}$ & $\begin{array}{c}50.32 \pm 2.53 \\
(+9.98)\end{array}$ & $\begin{array}{c}56.84 \pm 2.68 \\
(+24.24)\end{array}$ \\
\hline $\begin{array}{l}\text { Glucose } \\
(\mathrm{mg} / 100 \mathrm{ml})\end{array}$ & $65.30 \pm 3.30$ & $\begin{array}{c}61.43 \pm 3.45 \\
\quad(-5.93)\end{array}$ & $\begin{array}{c}57.89 \pm 3.31 \\
\quad(-11.35)\end{array}$ & $\begin{array}{c}50.01 \pm 3.02 \\
(-23.41)\end{array}$ \\
\hline $\begin{array}{l}\text { Cholesterol } \\
(\mathrm{g} / 100 \mathrm{ml})\end{array}$ & $0.43 \pm 0.09$ & $\begin{array}{l}0.44 \pm 0.06 \\
(+2.33)\end{array}$ & $\begin{array}{l}0.45 \pm 0.08 \\
(+4.65)\end{array}$ & $\begin{array}{c}0.46 \pm 0.06 \\
(+6.98)\end{array}$ \\
\hline $\begin{array}{l}\text { Lactic Acid } \\
(\mathrm{g} / 100 \mathrm{ml})\end{array}$ & $0.45 \pm 0.09$ & $\begin{array}{l}0.54 \pm 0.06 \\
(+18.32)\end{array}$ & $\begin{array}{c}0.61 \pm 0.06 \\
(+35.56)\end{array}$ & $\begin{array}{c}0.61 \pm 0.04 \\
(+35.56)\end{array}$ \\
\hline
\end{tabular}

Each value represents the mean \pm S.E.M. of five different observations. The values in parentheses denote percent change over control.

Sample size $(\mathrm{n})=15$ 
Carbaryl induced biochemical changes in Clarias batrachus.

Table 3. Effect of carbaryl on the activities of some enzymes from serum of $C$. batrachus exposed to the pesticide for $96 \mathrm{hr}$.

\begin{tabular}{|c|c|c|c|c|}
\hline \multirow[t]{2}{*}{ Enzymes } & \multirow[t]{2}{*}{ Control } & \multicolumn{3}{|c|}{ Carbaryl (mg/l) } \\
\hline & & 1 & 2 & 4 \\
\hline $\mathrm{LDH}^{\mathrm{a}}$ & $1.13 \pm 0.11$ & $\begin{array}{c}1.18 \pm 0.11 \\
(+4.42)\end{array}$ & $\begin{array}{c}1.24 \pm 0.13 \\
(+9.73)\end{array}$ & $\begin{array}{l}1.13 \pm 0.12 \\
(+22.12)\end{array}$ \\
\hline $\mathrm{AcP} \mathrm{P}^{\mathrm{b}}$ & $1.51 \pm 0.31$ & $\begin{array}{c}1.61 \pm 0.32 \\
(+6.62)\end{array}$ & $\begin{array}{c}1.79 \pm 0.29 \\
(+18.54)\end{array}$ & $\begin{array}{c}2.06 \pm 0.34 \\
(+36.42)\end{array}$ \\
\hline$A I P^{b}$ & $0.32 \pm 0.03$ & $\begin{array}{c}0.35 \pm 0.01 \\
(+9.34)\end{array}$ & $\begin{array}{c}0.37 \pm 0.03 \\
(+15.63)\end{array}$ & $\begin{array}{c}0.40 \pm 0.04 \\
(+25.0)\end{array}$ \\
\hline $\mathrm{GOP}^{\mathrm{c}}$ & $0.28 \pm 0.01$ & $\begin{array}{c}0.32 \pm 0.04 \\
(+14.29)\end{array}$ & $\begin{array}{c}0.39 \pm 0.03 \\
(+39.29)\end{array}$ & $\begin{array}{c}0.52 \pm 0.02 \\
(+85.71)\end{array}$ \\
\hline $\mathrm{GPT}^{\mathrm{c}}$ & $0.03 \pm 0.001$ & $\begin{array}{l}0.04 \pm 0.001 \\
(+33.33)\end{array}$ & $\begin{array}{c}0.05 \pm 0.001 \\
(+66.66)\end{array}$ & $\begin{array}{c}0.06 \pm 0.001 \\
(+100)\end{array}$ \\
\hline
\end{tabular}

a $\mu$ moles of NADH oxidized to $\mathrm{NAD}^{+} / \mathrm{hr} / \mathrm{mg}$ protein.

b $\mu$ moles of $\mathrm{p}$-nitrophenol released/hr/mg protein.

c $\mu$ moles of pyruvate released $/ \mathrm{hr} / \mathrm{mg}$ protein.

Each value represents the mean \pm S.E.M. of five different observations. The values in parentheses denote percent change over control.

Sample size $(\mathrm{n})=15$

Abbreviations: LDH, lactate dehydrogenase; AcP, acid phosphatase; AlP, alkaline phosphatase; GOT, glutamate oxaloacetate transaminase; GPT, glutamate pyruvate transaminase.

Table 4. Effect of carbaryl on the activities of some enzymes from the serum of $C$. batrachus exposed to the pesticide for 15 days.

\begin{tabular}{|c|c|c|c|c|}
\hline \multirow[t]{2}{*}{ Enzymes } & \multirow[t]{2}{*}{ Control } & \multicolumn{3}{|c|}{ Carbaryl (mg/l) } \\
\hline & & 1 & 2 & 4 \\
\hline $\mathrm{LDH}^{\mathrm{a}}$ & $1.13 \pm 0.12$ & $\begin{array}{l}1.29 \pm 0.13 \\
(+14.16)\end{array}$ & $\begin{array}{c}1.48 \pm 0.12 \\
(+30.97)\end{array}$ & $\begin{array}{l}1.68 \pm 0.11 \\
(+48.67)\end{array}$ \\
\hline $\mathrm{AcP} \mathrm{P}^{\mathrm{b}}$ & $1.51 \pm 0.31$ & $\begin{array}{l}1.72 \pm 0.31 \\
(+13.91)\end{array}$ & $\begin{array}{c}1.98 \pm 0.31 \\
(+31.13)\end{array}$ & $\begin{array}{l}2.24 \pm 0.32 \\
(+48.34)\end{array}$ \\
\hline $\mathrm{AlP} \mathrm{P}^{\mathrm{b}}$ & $0.32 \pm 0.03$ & $\begin{array}{l}0.38 \pm 0.03 \\
(+18.75)\end{array}$ & $\begin{array}{c}0.42 \pm 0.03 \\
(+31.25)\end{array}$ & $\begin{array}{l}0.50 \pm 0.04 \\
(+56.25)\end{array}$ \\
\hline GOT $^{\mathrm{c}}$ & $0.28 \pm 0.11$ & $\begin{array}{l}0.35 \pm 0.10 \\
(+25.00)\end{array}$ & $\begin{array}{c}0.48 \pm 0.11 \\
(+71.43)\end{array}$ & $\begin{array}{l}0.58 \pm 0.12 \\
(+107.43)\end{array}$ \\
\hline $\mathrm{GPT}^{\mathrm{c}}$ & $0.03 \pm 0.004$ & $\begin{array}{l}0.04 \pm 0.006 \\
(+33.33)\end{array}$ & $\begin{array}{c}0.05 \pm 0.007 \\
(+66.67)\end{array}$ & $\begin{array}{l}0.07 \pm 0.008 \\
(+133.33)\end{array}$ \\
\hline
\end{tabular}

a $\mu$ moles of $\mathrm{NADH}$ oxidized to $\mathrm{NAD}^{+} / \mathrm{hr} / \mathrm{mg}$ protein.

b $\mu$ moles of $\mathrm{p}$-nitrophenyl released $/ \mathrm{hr} / \mathrm{mg}$ protein.

c $\mu$ moles of pyruvate released $/ \mathrm{hr} / \mathrm{mg}$ protein.

Each value represents the mean \pm S.E.M. of five different observations. The values in parentheses denote percent change over control.

Sample size $(n)=15$

Abbreviations: LDH, lactate dehydrogenase; AcP, acid phosphatase; AIP, alkaline phosphatase; GOT, glutamate oxaloacetate transaminase; GPT, glutamate pyruvate transaminase. 


\section{B. SHARMA.}

ticides (Pant et al., 1987) and carbofuran (Mukhopadhyay et al., 1982). However, in C. punctatus the level of lactic acid was shown to decrease when the fish was exposed to quinolphos and monochrotophos (Samuel and Sastry, 1989) for a longer period of time (60 days). The accumulation of lactic acid (the end product of glycolysis) in serum and the decrease in the activity of succinate dehydrogenase in the liver is an indication of the inhibition of Kreb's cycle and/or a favor of anaerobic metabolism over aerobic metabolism due to intoxication by carbaryl (Sharma and Gopal, 1995). It also indicates the continuous operation of the glycolysis in fish tissues to meet the immediate energy demand and a portion of lactate being channelled into the blood (Sharma and Gopal, 1995). Further, the increased level of LDH activity in serum (Tables 3 and 4) indicates that the pesticide causes damage to fish tissues. The increased level of lactic acid has also been reported by Sastry and Siddiqui (1982) in C. punctatus exposed to sevin $(1.05 \mathrm{mg} / \mathrm{l})$ up to 60 days. The blood glucose level decreased in the pesticide-treated fish as compared to that of control, indicating thereby a hypoglycemic response. It has been shown that intestinal uptake of glucose is reduced in C. batrachus exposed to quinolphos (Sastry and Siddiqui, 1984). The low rate of absorption of glucose by the brush border in the intestine of the fish may be another possible reason for the hypoglycemic condition observed in the present study (Samuel and Sastry, 1989). The observed hypoglycemia could also be due to the increased rate of conversion of glucose into lactate under anaerobiosis to meet the energy demand by the organism for its survival (Sharma and Gopal, 1995; Singh and Sharma, 1998). The decrease in blood glucose level in C. punctatus exposed to endosulfan $(0.2 \mathrm{mg} / \mathrm{l})$ for 60 days has also been reported by Sastry and Siddiqui (1983).

The results of the present investigation suggested little influence of the carbaryl intoxication on the fish blood lipid profile (Tables 1 and 2). However, in another fresh-water fish, Barbus conchonius, exposed to aldicarb for 15 days, a marked increase in the level of cholesterol has been reported (Pant et al., 1987). Alkaline phosphatase is a brush border enzyme involved in the transphosphorylation reaction. In serum of carbaryltreated $C$. batrachus, the rise in the activities of alkaline phosphatase reflects alterations in the protein syn-

Table 5. Effect of carbaryl on the activities of certain key enzymes in the liver of C. batrachus exposed for 15 days.

\begin{tabular}{|c|c|c|c|c|}
\hline \multirow[t]{2}{*}{ Enzymes } & \multirow[t]{2}{*}{ Control } & \multicolumn{3}{|c|}{ Carbaryl (mg/l) } \\
\hline & & 1 & 2 & 4 \\
\hline $\mathrm{LDH}^{\mathrm{a}}$ & $1.09 \pm 0.01$ & $\begin{array}{l}1.00 \pm 0.09 \\
(-8.26)\end{array}$ & $\begin{array}{c}0.94 \pm 0.05 \\
(-13.76)\end{array}$ & $\begin{array}{c}0.70 \pm 0.05 \\
(-35.78)\end{array}$ \\
\hline $\mathrm{SDH}^{\mathrm{b}}$ & $27.35 \pm 0.81$ & $\begin{array}{c}25.18 \pm 0.83 \\
(-7.93)\end{array}$ & $\begin{array}{c}22.8 \pm 0.71 \\
(-16.64)\end{array}$ & $\begin{array}{c}20.81 \pm 0.67 \\
(-23.91)\end{array}$ \\
\hline $\mathrm{AcPc}$ & $2.86 \pm 0.12$ & $\begin{array}{l}2.60 \pm 0.11 \\
(-9.09)\end{array}$ & $\begin{array}{c}2.53 \pm 0.12 \\
(-11.54)\end{array}$ & $\begin{array}{l}2.31 \pm 0.11 \\
(-19.23)\end{array}$ \\
\hline $\mathrm{AlP}^{\mathrm{C}}$ & $0.97 \pm 0.02$ & $\begin{array}{l}0.95 \pm 0.02 \\
(-2.06)\end{array}$ & $\begin{array}{c}0.93 \pm 0.02 \\
(-4.12)\end{array}$ & $\begin{array}{c}0.90 \pm 0.01 \\
\quad(-7.22)\end{array}$ \\
\hline $\mathrm{GOT}^{\mathrm{d}}$ & $0.37 \pm 0.03$ & $\begin{array}{l}0.41 \pm 0.03 \\
(+11.92)\end{array}$ & $\begin{array}{c}0.59 \pm 0.03 \\
(+59.08)\end{array}$ & $\begin{array}{l}0.82 \pm 0.03 \\
(+123.30)\end{array}$ \\
\hline $\mathrm{GPT}^{\mathrm{d}}$ & $0.50 \pm 0.012$ & $\begin{array}{l}0.511 \pm 0.011 \\
(+2.0)\end{array}$ & $\begin{array}{l}0.513 \pm 0.014 \\
(+4.39)\end{array}$ & $\begin{array}{c}0.534 \pm 0.010 \\
(+6.59)\end{array}$ \\
\hline
\end{tabular}

a $\mu$ moles of $\mathrm{NADH}$ oxidized to $\mathrm{NAD}^{+} / \mathrm{hr} / \mathrm{mg}$ protein.

b $\mu$ moles of formazan formed $/ \mathrm{hr} / \mathrm{mg}$ protein.

c $\mu$ moles of $\mathrm{p}$-nitrophenol released $/ \mathrm{hr} / \mathrm{mg}$ protein.

$\mathrm{d} \mu$ moles of pyruvate released/hr/mg protein.

Each value represents the mean \pm S.E.M. of five different observations. The values in parentheses denote percent change over control.

Sample size $(n)=15$

Abbreviations: LDH, lactate dehydrogenase; SDH, succinate dehydrogenase; AcP, acid phosphatase; AlP, alkaline phosphatase; GOT, glutamate oxaloacetate transaminase; GPT, glutamate pyruvate transaminase. 
thesis and uncoupling of oxidative phosphorylation. Acid phosphatase is a lysosomal enzyme which aids the autolysis of the cell after its death. The increase in the level of this enzyme in serum of $C$. batrachus may be due to structural damage in the liver and hence the leakage of the enzyme into extracellular compartments caused by carbaryl toxicity (Mahajan and Sharma, 1984; Shobharani et al., 1989; Gill et al., 1990).

The increase in the activities of GOT and GPT in the blood of C. batrachus exposed to carbaryl for $96 \mathrm{hr}$ and 15 days suggested that there was increase in the transamination processes and also that protein was increasingly metabolized. This notion is further supported by the decrease in the level of protein under pesticide stress (Tables 1 and 2). The cellular damage during pesticide stress may also cause mitochondrial enzyme to seep into the cytoplasm, thus enhancing the enzyme activities. Similar findings are reported in $C$. batrachus exposed to sublethal concentrations of carbofuran (0.1 to $0.5 \mathrm{mg} / \mathrm{l}$ ) (Mukhopadhyay et al., 1982; Kumari et al., 1997; Yadav et al., 1998) and in C. punctatus exposed to subacute concentrations of aldicarb for 30 days (Pant et al., 1987). GOT and GPT are often used to assess the impact of sublethal toxicity of environmental pollutants in fish (Loroux and Perry, 1972). The present results showing an increase in the activities of GOT and GPT in liver (Table 5) and the serum (Tables 3 and 4) suggest probable alterations in the pathophysiological status of the liver as well as an increased turnover of protein in $C$. batrachus due to pesticide toxicity.

In conclusion, carbaryl at sublethal concentrations exerted its toxic manifestations in C. batrachus leading to the onset of an energy crisis. The decrease in the activity of carbaryl-treated SDH in the liver and increase in lactic acid content in blood of $C$. batrachus suggest an impairment of aerobic processes in favor of anaerobic processes, possibly to meet the energy requirement due to pesticide intoxication. The observed alterations in energy metabolism may also be a reflection of toxic effects such as inhibition of acetylcholinesterase (AChE) activity by carbaryl in C. batrachus (Sharma et al., 1993a), which leads to increased motor activity and thus creates higher energy demands. This is supported by the increase in the activities of transaminases which may be helpful in energy supplementation through gluconeogenesis. Thus, it appears that the pesticide has induced an energy crisis and altered the protein metabolism, forcing the fish to adapt an alternative energyproducing mechanism to survive. Further studies are in progress to understand the exact mechanism(s) involved in the biochemical changes following carbaryl treatment.

\section{ACKNOWLEDGMENTS}

The financial support from the All India Council for Technical Education-New Delhi is acknowledged.

\section{REFERENCES}

Barker, S. B. and Summerson, W. H. (1941): The colorimetric determination of lactic acid in biological material. J. Biol. Chem., 138, 535-554.

Bergemeyer, H.U. (1965): In Methods of Enzymatic Analysis (Bergemeyer, H. U. ed.), 2, p.375, Academic Press, New York.

Fisher, R. A. (1950): In Statistical Methods for Research Workers (Oliver and Boyd, eds.), London.

Gill, T. J., Pande, J. and Tewari, H. (1990): Enzyme modulation by sublethal concentrations of aldicarb phosphomidon and endosulfan in fish tissues. Pest. Biochem. Physiol., 38, 231-244.

Gopal, K., Pathak, S. P. and Sharma, B. (1992): Xenobiotics induced stress mediated immunodeficiency and disease syndromes in fresh water fish. Int. J. Toxicol. Occup. Environ. Health. 1, 39-45.

Kaundilya, P. R. and Ramamurti, R. (1980): Toxicity of sumithion and sevin to the fresh water fish, $S$. mosambicus (Peters). Curr. Sci., 49, 875-879.

Kaushal, N. A. and Sharma, B. (1985): Rapid purification of lactate dehydrogenase from $S$. cervi by affinity chromatography. Indian J. Parasitol., 9, 297-299.

Kumari, R., Singh, R. K., Khanna, Y. P. and Sharma, B. (1997): Carbofuran induced stress-mediated disease syndromes in C. batrachus, a fresh water fish. Proc. Int. Conference of Pollution Assessment, pp.278-295.

Loroux, M. and Perry, W. F. (1972): Transaminases as markers of environment pollutants. Clin. Biochem., 5, 201-215.

Lowry, O. H., Rosebrough, N. J., Farr, A. L. and Randall, R. J. (1951): Protein measurement with Folin-Phenol reagent. J. Biol. Chem., 193, 265275.

Mahajan, C. L. and Sharma, K. C. (1984): Effect of feeding aldrin contaminated diet on mortality, growth and certain biochemical parameters of the fish, C. punctatus (Bloch). Proc. Natl. Acad. Sci., India, 54, (B), 11-16. 
Mowdesley Thomas, L. E. (1971): Toxic chemicals: the risk of the fish. New Scientist, 49, 74-75.

Mukhopadhyay, P. K., Mukherjee, A. P. and Dehadri, P. V. (1982): Certain biochemical responses in the air breathing cat fish, C. batrachus exposed to sublethal carbofuran. Toxicology, 23, 337-342.

Oser, B. L. (1979): In Hawk's Physiological Chemistry, 14th Edn., Tata Mc Graw-Hill Publishing Co., Ltd., New York.

Pant, J., Tewari, H. and Gill, T. S. (1987): Effect of aldicarb on the blood and tissues of a fresh water fish. Bull. Environ. Contam. Toxicol., 38, 36-41.

Park, J. T. and Johnson, M. J. (1963): In Methods in Enzymol. (Colowick, S. P. and Kaplan, N. O., eds.).

Plummer, D. T. (1971): In An introduction to practical biochemistry (Eds. Tata Mc Graw-Hill Co., Ltd.), Delhi.

Samuel, M. and Sastry, K. V. (1989): In vitro effect of monocrotophos on the carbohydrate metabolism of the fresh water snake-head fish, C. punctatus. Pest. Biochem. Physiol., 34, 1-8.

Sastry, K. V. and Siddiqui, A. A. (1982): Chronic toxic effects of the carbamate pesticide sevin on carbohydrate metabolism in a fresh water snake-head fish, C. punctatus. Toxicol. Letters, 14, 123-130.

Sastry, K. V. and Siddiqui, A. A. (1983): Metabolic changes in the snake-head fish, C. punctatus chronically exposed to endosulfan. Water, Air and Soil Pollut., 19, 133-137.

Sastry, K. V. and Siddiqui, A. A. (1984): Some hematological, biochemical and enzymological parameters of a fresh water teleost fish, C. punctatus, exposed to sublethal concentrations of quinolphos. Pest. Biochem. Physiol., 22, 8-13.
Saxena, P. K., Singh, V. P., Kendal, J. K. and Soni, G. L. (1988): Effect of malathion and carbofuran on in vitro lipid and protein synthesis of liver of the fresh water teleost, C. punctatus. Indian J. Exp. Biol., 26, 100-105.

Sharma, B. and Gopal, K. (1995): Changes in lactic acid content and activity of lactate dehydrogenase in C. batrachus exposed to carbaryl. Toxicol. Environ. Chem., 47, 89-95.

Sharma, B., Gopal, K. and Khanna, Y. P. (1993a): Interaction of carbaryl with acetylcholinesterase of the teleost, C. batrachus. Toxicol. Environ. Chem., 39, 147-152.

Sharma, B., Lata, S., Ram, M. D. and Gopal, K. (1993b): Carbaryl induced alterations in the level of biogenic amines in various parts of the brain of C. batrachus. Toxicol. Environ. Chem., 38, 9599.

Singh, R. K. and Sharma, B. (1998): Carbofuran induced biochemical changes in C. batrachus. Pest. Sci., 53, 285-290.

Shobharani, V. J., Venkateshwarlu, P. and Janaiah, C. (1989): Changes in carbohydrate metabolism of $C$. batrachus (Linn.) when exposed to two organophosphorus insecticides. J. Environ. Biol., 10, 197-204.

Srikantan, T. N. and Krishnamurti, C. R. (1955): Tetrazolium tests for dehydrogenases. J. Sci. Ind. Res., 14, 206-211.

Yadav, A., Singh, R. K. and Sharma, B. (1998): Interaction of carbofuran with acetylcholinesterase from the brain of the teleost, C. batrachus. Toxicol. Environ. Chem., 65, 245-254.

Zlatkis, A., Zak, B. and Bayle, A. J. (1953): A new method for direct determination of serum cholesterol. J. Lab. Clin. Med., 41, 486-491. 